\title{
PERANAN PEREMPUAN DALAM MEMBANGUN KINERJA KOPERASI SIMPAN PINJAM BERPRINSIP SYARIAH (STUDI KASUS KSU HUWAIZA DEPOK)
}

\author{
Lindiawatie $^{1}$, Dhona Shahreza ${ }^{2}$, Anita Ria ${ }^{3}$ \\ ${ }^{1,2,3}$ Program Studi Pendidikan Ekonomi, \\ Fakultas Ilmu Pendidikan dan Pengetahuan Sosial \\ Universitas Indraprasta PGRI Jakarta \\ Email : lindammanaf@gmail.com
}

Diterima: Juni 2018; Disetujui: Juli 2018; dipublikasikan: 31 Agustus 2018

\begin{abstract}
ABSTRAK
Kebijakan kesetaraan gender dalam SDGs adalah meningkatkan kualitas dan peran perempuan di berbagai bidang pembangunan. Salah satu pemberdayaan gender dalam pembangunan adalah berdirinya koperasi simpan pinjam Huwaiza yang dibentuk atas inisiatif kaum perempuan yang aktif dalam komunitas pengajian dengan sistem operasional syariah. Tujuan penelitian ini adalah untuk mengetahui peranan perempuan dalam membangun kinerja koperasi yang berlandaskan syariah. Jenis penelitian ini adalah penelitian kualitatif dengan metode pengambilan data melalui wawancara dan dokumentasi. Peran perempuan dalam membangun kinerja koperasi berprinsip syariah adalah membagi tugas sesuai gender menurut prinsip kesetaraan gender dan non diskriminatif, mendorong fungsi manajemen sebagai pengelola senantiasa meningkatkan kinerja dengan melibatkan saran dan masukan pengawas bidang manajemen, menjaga operasionalisasi koperasi supaya tetap berada di jalur syariah dengan melibatkan pengawas bagian syariah. Dengan terwujudnya prinsip kesetaraan gender yang tepat melalui pembagian tugas yang bersifat non diskriminatif dan adil membuat koperasi syariah mampu meningkatkan aset dan jumlah anggotanya.
\end{abstract}

\section{Kata kunci : Perempuan, Kinerja, Koperasi Syariah.}

\begin{abstract}
The policy of gender equality in the SDGs are improving the quality and the role of women in the various areas of development. One of gender empowerment is the establishment of the cooperative Huwaiza formed on the initiative of women. The purpose of research is to know the role of women in building the performance of cooperatives based on Sharia. This type of research is qualitative through interviews and documentation. The role of women in building cooperative performance is gender appropriate task according to the principle of gender equality, encourage management functions as the Manager always improves performance by involving the advice of Trustees management field, keeping the cooperative in line with its syariah supervisory. With the realization of the principle of gender equality through the proper division of tasks a non discriminatory and unfair to make sharia was able to increase cooperative assets and number of members.
\end{abstract}

\section{Keywords : Women, Performance, Sharia Cooperative}


Volume 10, No. 2, Agustus 2018, pp. 96-108

e-ISSN: 2502-5449

p-ISSN: 2085-2266

http://journal.lppmunindra.ac.id/index.php/sosio_ekons

\section{PENDAHULUAN}

Pada September 2015 Perserikatan Bangsa-bangsa (PBB) meluncurkan program pembangunan berkelanjutan (Sustainable Development Goals) atau SDGs sebagai pengganti MDGs (Milenium Developtment Goals). SDGs memiliki 17 program yang berlaku bagi negaranegara maju dan berkembang. SDGs direncanakan untuk 15 tahun ke depan atau yang biasa dikenal agenda 2030. Tujuh belas program tersebut menurut Bappenas (2017) adalah 1) Tanpa kemiskinan, 2) Tanpa kelaparan, 3) Kehidupan sehat dan sejahtera, 4) Pendidikan berkualitas, 5) Kesetaraan gender, 6) Air bersih dan sanitasi layak, 7) Energi bersih dan terjangkau, 8) Pekerjaan layak dan pertumbuhan ekonomi, 9) Industri, inovasi dan infrastruktur, 10) Berkurangnya kesenjangan, 11) Kota dan pemukiman yang berkelanjutan, 12) Konsumsi dan produksi yang bertanggung jawab, 13) Penanganan perubahan iklim, 14) Ekosistem laut, 15) Ekosistem daratan, 16) Perdamaian, keadilan dan kelembagaan yang tangguh, 17) Kemitraan untuk mencapai tujuan.

Tujuan pembangunan berkelanjutan menurut Bappenas (2017) adalah pembangunan yang menjaga peningkatan kesejahteraan ekonomi masyarakat secara berkesinambungan, pembangunan yang menjaga keberlanjutan kehidupan sosial masyarakat, pembangunan yang menjaga kualitas lingkungan hidup serta pembangunan yang menjamin keadilan dan terlaksananya tata kelola yang mampu menjaga peningkatan kualitas hidup dari satu generasi ke generasi berikutnya. Intinya tujuan pembangunan berkelanjutan yang ingin diwujudkan sampai dengan tahun 2030 mendatang adalah upaya untuk menjamin terpeliharamya 3 pilar dalam kehidupan yaitu keadilan di bidang sosial, ekonomi dan lingkungan.

Isu kesetaraan gender merupakan tujuan ke-5 dari ke-17 program SDGs. Dalam Rencana Pembangunan Jangka Menengah Nasional 2015-2019 (RPJMN 2015-2019) yang dirumuskan oleh Bappenas, kebijakan pada bagian kesetaraan gender adalah 1) Meningkatkan kualitas dan peran perempuan di berbagai bidang pembangunan, 2) Menekankan peran perempuan di bidang politik, dan 3) Meningkatkan kapasitas kelembagaan pengarusutamaan gender.

Perempuan di abad milenial ini memiliki kedudukan yang sama dengan laki-laki dalam seluruh bidang kehidupan sosial, ekonomi, politik, hukum dan lain-lain sebagainya. Perempuan yang beraktivitas di luar rumah kini telah menjadi kelaziman di masyarakat baik masyarakat domestik maupun global. Peran perempuan pada abad milenium ini menjadi fokus perhatian dalam pembangunan di negara maju dan berkembang. Bappenas sebagai lembaga pemeringah yang membuat perencanaan dan kebijakan-kebijakan pembangunan nasional telah membuat panduan dalam rangka mewujudkan target SDGs untuk pemerintah daerah dan kota di Indonesia. Salah satunya adalah bagaimana melibatkan peran aktif perempuan dalam berbagai bidang pembangunan. Pemerintah daerah berlomba-lomba memberikan perhatian pada isu kesetaraan gender ini.

Kesetaraan gender ini diukur melalui Indeks Pemberdayaan Gender (IPG), yaitu suatu indikator yang menunjukkan tingkat partisipasi aktif perempuan dalam bidang ekonomi dan politik. Menurut Kementerian Pemberdayaan Perempuan dan Anak (2016), dengan mengunakan angka IPG maka dapat diketahui perbedaan pencapaian pembangunan manusia berbasis gender. Semakin dekat angka IPG ke 100, maka semakin rendah kesenjangan gender.

Data UNDP 2015 yang dikutip oleh Kementerian Pemberdayaan Perempuan dan Anak menunjukkan Angka IPG Indonesia pada 2015 mencapai 92,74. Terdapat 5 provinsi dengan angka IPG tertinggi di atas angka IPG nasional, yaitu Sumatera Barat $(92,74)$, DKI Jakarta $(92,72)$, Sulawesi Utara $((94,64)$, DI Yogyakarta $(94,41)$ dan Kepulauan Riau $(93,20)$. Sedangkan Jawa Barat selama 2010-2015 termasuk salah satu dari 5 provinsi yang terus mengalami peningkatan angka IPG. Kelima daerah yang mengalami peningkatan IPG adalah Kalimantan Barat $(85,61)$, Gorontalo $(85,67)$, Jawa Barat $(89,11)$ Sumatera Barat $(94,74)$ dan Sulawesi Tenggara $(90,30)$. 
Volume 10, No. 2, Agustus 2018, pp. 96-108

e-ISSN: 2502-5449

p-ISSN: 2085-2266

http://journal.lppmunindra.ac.id/index.php/sosio_ekons

Di wilayah Jawa Barat sendiri, Kota Depok merupakan kota yang memiliki angka IPG tertinggi $(81,23 \%)$ dibandingkan dengan kota-kota lainnya di Jawa Barat seperti diperlihatkan pada Tabel 1 berikut.

Tabel 1. Data IPG Kota-kota di Jawa Barat 2015

\begin{tabular}{c|l|c}
\hline No & \multicolumn{1}{|c|}{ Kota } & IPG \\
\hline 1. & Kota Bogor & 64,05 \\
\hline 2. & Kota Sukabumi & 59,42 \\
\hline 3. & Kota Bandung & 58,06 \\
\hline 4. & Kota Cirebon & 74,89 \\
\hline 5. & Kota Bekasi & 64,84 \\
\hline 6. & Kota Depok & 81,23 \\
\hline 7. & Kota Cimahi & 73,38 \\
\hline 8. & Kota Tasikmalaya & 62,46 \\
\hline 9. & Kota Banjar & 49,32 \\
\hline \multicolumn{2}{l|}{ Sumber: jabar.bps.go.id }
\end{tabular}

Angka IPG yang terbesar di Kota Depok memperlihatkan bahwa partisipasi aktif dan peranan perempuan di bidang pembangunan ekonomi dan politik di wilayah Depok sangat tinggi. Angka IPG yang sangat tinggi menunjukkan besarnya kontribusi perempuan dalam pembangunan. Kebanyakan perempuan di Kota Depok ikut mendorong keberhasilan pembangunan Depok. Perempuan di Kota Depok turut berpartisipasi aktif berusaha meningkatkan prestasi dalam pembangunan.

Salah satunya adalah Koperasi Serba Usaha (KSU) Huwaiza yang dibentuk atas inisiatif kaum perempuan yang aktif dalam komunitas pengajian. KSU Huwaiza merupakan salah satu koperasi jasa keuangan yang dibangun dengan sistem operasionalisasi syariah. Didirikan atas inisiatif komunitas pengajian yang anggotanya semuanya adalah perempuan yang dilatari dalam rangka memenuhi kebutuhan perempuan sebagai ibu rumah tangga.

Berdasarkan latar belakang tersebut, maka dibuatlah rumusan pertanyaan dalam penelitian ini yaitu bagaimanakah peranan perempuan dalam membangun kinerja pada Koperasi Serba Usaha (KSU) Huwaiza yang berlandaskan syariah? Dari pertanyaan penelitian tersebut maka tujuan penelitian ini adalah untuk mengetahui peranan perempuan dalam membangun kinerja KSU Huwaiza yang berlandaskan syariah.

Koperasi syariah atau yang lebih dikenal dengan istilah BMT (Baitul Maal wa Tamwil) adalah bentuk payung hukum yang melandasi kegiatan operasional BMT. BMT atau Balai Usaha Mandiri Terpadu adalah lembaga keuangan mikro yang dioperasikan dengan prinsip bagi hasil, menumbuhkembangkan bisnis usaha mikro dan kecil, dalam rangka mengangkat derajat dan martabat serta membela kepentingan kaum fakir miskin. BMT adalah lembaga bisnis, membuat keuntungan tetapi juga memiliki komitmen yang kuat untuk membela kaum yang lemah dalam penanggulangan kemiskinan (Aziz, $2005: 1$ ).

Menurut Aziz (2005 : 2), tujuan BMT berdiri adalah menciptakan sistem, lembaga dan kondisi kehidupan ekonomi rakyat banyak yang dilandasi oleh nilai-nilai dasar salaam, keselamatan berintikan keadilan, kedamaian dan kesejahteraan. Kegiatan usaha BMT adalah : a. Mengembangkan kegiatan simpan pinjam dengan prinsip bagi hasil/syariah. b. Mengembangkan lembaga dan bisnis kelompok usaha muamalah yaitu kelompok simpan pinjam yang khas binaan BMT. c.Memprakarsai pengembangan badan usaha sektor riil yang manajemennya terpisah dari BMT. d.Mengembangkan jaringan kerja dan jaringan bisnis BMT dan sektor riil mitranya.

BMT didirikan dengan prinsip-prinsip dasar sebagai berikut (Aziz, 2005:20) : 1. Mengutamakan mutu hasil kerja terbaik (ahsan), terindah (thayyiban), memuaskan semua pihak 


\section{Sosio e-kons}

Volume 10, No. 2, Agustus 2018, pp. 96-108

e-ISSN: 2502-5449

p-ISSN: 2085-2266

http://journal.lppmunindra.ac.id/index.php/sosio_ekons

(ahsanu 'amala), sesuai nilai-nilai salaam, keselamatan, kedamaian dan kesejahteraan. 2. Pengelolaan lembaga dan usaha berlandaskan barakah, berdaya guna, berhasil guna, penguatan jaringan, transparan dan bertanggung jawab sepenuhnya kepada publik. 3.Menguatkan kesamaan visi dan misi berlandaskan penguatan ruhiyah (spiritual communication). 4.Demokratis, partisipatif dan inklusif. 5.Keadilan sosial, kesetaraan gender, non diskriminatif. 6. Ramah lingkungan. 7.Peka terhadap dan memanfaatkan secara bijak pengetahuan dan budaya lokal serta keanekaragaman budaya. 8.Keberlanjutan, memberdayakan masyarakat dengan meningkatkan kemampuan diri dan lembaga masyarakat lokal.

Adapun peran BMT sebagaimana dijabarkan dalam Aziz (2005 : 23) adalah sebagai berikut: 1. Motor penggerak ekonomi dan sosial masyarakat banyak, 2.Ujung tombak pelaksanaan ekonomi syariah. 3.Penghubung antara kaum berada (aghniya) dan kaum yang lemah (dhuafa). 4.Sarana pendidikan informal untuk mewujudkan prinsip hidup yang barakah, ahsanu 'amala dan salaam melalui spiritual communication dzikir qalbiyah ilahiah.

Jenis koperasi dapat dibedakan berdasarkan bidang usaha, jenis komoditi, jenis profesi anggota dan daerah kerja.

1. Berdasarkan bidang usahanya

Penggolongan koperasi berdasarkan bidang usahanya mencerminkan jenis jasa yang ditawarkan koperasi kepada pelanggannya. a. Koperasi Konsumsi adalah koperasi yang berusaha dalam bidang penyediaan barang-barang konsumi yang dibutuhkan oleh para anggotanya. Jenis konsumsi yang dilayani oleh suatu koperasi konsumsi tergantung pada ragam anggota dan daerah kerja tempat koperasi didirikan. b. Koperasi Produksi adalah yang kegiatan utamanya memproses bahan baku menjadi barang jadi atau setengah jadi. Tujuannya adalah untuk menyatukan kemampuan dan modal para anggotanya guna meningkatkan barang-barang tertentu melalui proses yang meratakan pengelolaan dan memiliki sendiri. c. Koperasi Pemasaran adalah koperasi yang dibentuk terutama untuk membantu para anggotanya dalam memasarkan barang-barang yang dihasilkannya. Tujuannya adalah untuk menyederhanakan mata rantai tata niaga, dan mengurangi sekecil mungkin keterlibatan perantara di dalam memasarkan produk-produk yang dihasilkan. d. Koperasi kredit atau Simpan Pinjam adalah koperasi yang bergerak dalam pemupukan simpanan dari para anggotanya untuk dipinjamkan kembali kepada anggotanya yang membutuhkan bantuan modal untuk usahanya. Selain itu, koperasi simpan pinjam juga bertujuan mendidik anggotanya untuk bersifat hemat dan gemar menabung serta mengindarkan anggotanya dari jeratan para rentenir.

2. Berdasarkan jenis komoditi

Berdasarkan jenis komoditinya, maka koperasi dapat dibedakan menjadi: a. Koperasi ekstraktif adalah koperasi yang melakukan usahanya dengan menggali atau memanfaatkan sumber-sumber alam secara langsung tanpa atau dengan sedikit mengubah bentuk dan sifat sumber alam itu. b. Koperasi pertanian dan peternakan koperasi-koperasi pertanian adalah koperasi yang melakukan usaha berhubungan dengan komoditi pertanian tertentu. Koperasi ini beranggotakan para petani, buruh tani atau berhubungan dengan usaha pertanian. Kegiatan koperasi pertanian biasanya meliputi: 1). Pengusahaan bibit, semprotan dan peralatan pertanian lainnya. 2). Mengolah hasil pertanian. 3). Memasarkan hasil-hasil olahan komoditi pertanian. 4). Menyediakan modal bagi para petani. c. Koperasi peternakan adalah koperasi yang usahanya berhubungan dengan peternakan tertentu. Anggota biasanya pemilik pertanian dan pekerja yang berkaitan dengan usaha peternakan. d. Koperasi industri dan kerajinan adalah koperasi yang melakukan bidang usaha di bidang indusrti dan kerajinan tertentu. Usahanya meliputi usaha pengadaan, pengolahan bahan baku menjadi barang jadi atau gabungan ketiganya. e. Koperasi jasa-jasa. Koperasi jasa hampir sama dengan koperasi industri lainnya, yang membedakan ialah bahwa koperasi jasa mengkhususkan usahanya dalam memproduksi dan memasukkan kegiatan-kegiatan tertentu. Sebagaimana koperasi industri, tujuan koperasi jasa adalah untuk menyatukan potensi ekonomi yang dimiliki oleh 


\section{Sosio e-kons}

Volume 10, No. 2, Agustus 2018, pp. 96-108

e-ISSN: 2502-5449

p-ISSN: 2085-2266

http://journal.lppmunindra.ac.id/index.php/sosio_ekons

masing-masing anggotanya. Contohnya adalah jasa audit, koperasi jasa angkutan, dan lainlain.

3. Koperasi berdasarkan profesi anggotanya

Istilah profesi sebenarnya mempunyai arti sebagai jenis pekerjaan yang dilakukan orang-orang yang mempunyai keahlian atau kecakapan tertentu berdasarkan kode etik.

Berdasarkan profesi anggotanya, koperasi dapat dibedakan menjadi: a. Koperasi Karyawan, b. Koperasi Pegawai Negeri Sipil, c. Koperasi Angkatan Darat, Laut, Udara, dan Polri. d. Koperasi Mahasiswa, e. Koperasi Pedagang Pasar, f. Koperasi Veteran Republik Indonesia, g. Koperasi Nelayan, h. Koperasi Kerajinan, dan sebagainya.

4. Koperasi berdasarkan daerah kerjanya

Daerah kerja koperasi di sini adalah Luas-sempit wilayah yang ditinjau oleh suatu badan usaha koperasi dalam melayani kepentingan para anggotanya atau melayani masyarakat. Berdasarkan daerah kerjanya koperasi digolongkan sebagai berikut: a. Koperasi primer adalah Koperasi yang beranggotakan orang yang biasanya didirikan pada lingkup wilayah tertentu. b. Koperasi pusat adalah Koperasi yang beranggotakan koperasi-koperasi primer biasanya didirikan sebagai pemusatan dari berbagai koperasi primer dalam lingkup wilayah tertentu. Koperasi pusat mempunyai tujuan untuk memperkuat kedaulatan ekonomi koperasi-koperasi yang bergabung di dalamnya. c. Koperasi gabungan, koperasi gabungan hampir sama denga koperasi pusat, koperasi gabungan tidak beranggotakam orang-orang, melainkan beranggotakan koperasi-koperasi pusat yang berasal dari wilayah tertentu. Tujuan pembentukannya adalah untuk memperkuat kedudukan koperasi-koperasi yang bergabung di dalamnya, di wilayah kerja yang lebih luas. d.Koperasi induk ialah Koperasi yang beranggotakan berbagai koperasi pusat atau koperasi-koperasi gabungan yang berkedudukan di ibukota negara. Fungsinya ialah sebagai penyambung lidah koperasi-koperasi yang menjadi anggotnya dalam berhubungan dengan lembaga nasional yang terkait dengan pembinaan koperasi-koperasi sejenis di negara lain ataupun organisasi-organisasi pengusaha pada tingkat nasional dan internasional. Contoh: Induk Koperasi Pegawai Negeri (IKPN), Induk Koperasi Karyawan (Inkopkar), dan lain sebagainya.

\section{METODE}

Jenis penelitian ini adalah penelitian kualitatif. Menurut Sugiyono (2010 : 13), metode penelitian kualitatif dapat diartikan sebagai metode penelitian yang berlandaskan pada filsafat postpostivisme, digunakan untuk meneliti pada kondisi obyek yang alamiah (lawan dari eksperimen), dimana peneliti adalah instrumen utama, pengambilan data dilakukan secara purposive atau snow ball, teknik pengumpulan dengan triangulasi, analisa data bersifat induktif dan hasil penelitian lebih menekankan makna daripada generalisasi.

Lokasi penelitian adalah koperasi syariah yang berada di wilayah Kota Depok. Koperasi syariah yang dijadikan obyek adalah koperasi yang menjalankan usaha simpan pinjam kepada para anggotanya. Koperasi syariah yang dimaksud adalah Koperasi Serba Usaha (KSU) Huwaiza yang beralamat di Cinere, Depok, Jawa Barat.

Metode pengambilan data dilakukan dengan dua cara; pertama, pengambilan data primer, yaitu suatu bentuk pengambilan data yang dilakukan dengan terjun langsung ke lapangan menemui sumber-sumber informan, dengan cara melakukan wawancara kepada pengurus koperasi syariah. Kedua, pengambilan data sekunder. Pengambilan data sekunder dilakukan melalui studi pustaka dan mengumpulkan dokumentasi data-data antara lain tentang riwayat, portofolio pembiayan, kepengurusan, operasional sehari-hari koperasi melalui pengurus koperasi.

Populasi dalam penelitian kualitatif adalah situasi sosial yang terdiri atas 3 elemen menurut Spradley dalam Sugiyono (2010 : 389), yaitu : tempat, pelaku dan aktivitas. Dengan 


\section{Sosio e-kons}

Volume 10, No. 2, Agustus 2018, pp. 96-108

e-ISSN: 2502-5449

p-ISSN: 2085-2266

http://journal.lppmunindra.ac.id/index.php/sosio_ekons

demikian populasi atau situasi sosial yang dimaksud dalam peneltian ini adalah tempat penelitian yang berada di koperasi syariah, KSU Huwaiza di Depok, peneliti sebagai pelaku

penelitian dan pengelola koperasi syariah sebagai obyek penelitian serta aktivitas wawancara yang dilakukan oleh peneliti terhadap pengurus koperasi syariah.

Sedangkan teknik pengambilan sampelnya adalah dengan teknik pengambilan sampel purposive sampling, yaitu teknik pengambilan sampel sumber data dengan pertimbangan tertentu, dimana pertimbangan tertentu yang dimaksud yaitu pengambilan data langsung dari pengelola koperasi yang dianggap paling mengetahui data-data dan berbagai pendekatanpendekatan atau upaya-upaya apa saja yang selama ini telah dijalankan dalam membangun kinerja dan prestasi sebagai institusi koperasi yang berbasis syariah di Depok.

Instrumen penelitian menurut Arikunto (2013: 203) adalah alat atau fasilitas yang digunakan oleh peneliti dalam mengumpulkan data agar pekerjaannya lebih mudah dan hasilnya lebih baik, dalam arti lebih cermat, lengkap dan sistematis sehingga lebih mudaah diolah. Variasi jenis instrumen banyak, antara lain angket, check list dan pedoman wawancara. Instrumen dalam penelitian ini terdiri atas peneliti sebagai instrumen kunci sebagaimana dikatakan oleh Sugiyono bahwa dalam penelitian kualitatif, yang menjadi instrumen atau alat penelitian kunci adalah peneliti itu sendiri (2010: 398). Sedangkan instrumen lain yang digunakan adalah sebagai berikut: 1 . Wawancara (interview), Wawancara atau interview adalah dialog berupa tanya-jawab yang dilakukan oleh pewawancara (peneliti) kepada pengelola koperasi KSU Huwaiza untuk memperoleh informasi secara komprehensif tentang peranan komunitas perempuan yang selama ini telah membangun kinerja dan upaya mewujudkan prestasinya sebagai lembaga koperasi yang berlandaskan syariah. 2. Dokumentasi, Dokumentasi berasal dari kata dokumen artinya barang-barang tertulis. Melalui instrumen dokumentasi ini peneliti memperoleh informasi melalui sumber-sumber tertulis seperti dokumen-dokumen pembiayaan yang terdiri atas data-data tentang keanggotaan koperasi, data-data tentang kegiatan pembiayaan yang telah dilakukan selama ini, antara lain berupa laporan keuangan dan bentukbentuk dokumentasi lain yang menunjang informasi penelitian ini.

Analisis data dalam penelitian kualitatif bersifat induktif, yaitu suatu analisis yang diperoleh berdasarkan data yang didapatkan dari lapangan melalui berbagai metode antara lain wawancara dan dokumentasi selanjutnya hasil wawancara dianalisa secara mendalam dengan menggunakan pustaka-pustaka yang mendukung hasil wawancara dan dokumentasi, kemudian disimpulkan. Kesimpulan tersebut merupakan cikal bakal hipotesis yang dapat berkembang menjadi teori.

Dalam penelitian kualitatif yang bersifat induktif ini, analisis data lebih difokuskan selama proses di lapangan bersamaan dengan pengumpulan data. Tahapan teknik analisis data dalam penelitian ini adalah sebagai berikut: 1 . Pengumpulan data, Pengumpulan data dilakukan sewaktu proses wawancara dan pengumpulan dokumen-dokumen selama berinteraksi dengan pengurus koperasi syariah di lapangan. 2. Reduksi data, Setelah data-data yang diperoleh melalui wawancara dan proses dokumentasi dinilai cukup selanjutnya melakukan penyortiran data atau memilah-milah jenis data dan informasi yang sesuai dengan judul penelitian. 3 . Penyajian data, Data dan informasi yang telah dipisahkan selanjutnya dianalisa dengan pendekatan pustaka-pustaka yang lain seperti teori-teori sebelumnya, hasil-hasil penelitian, jurnal-jurnal, buku-buku dan informasi lain yang mendukung keabsahan hasil penelitian ini. 4. Penarikan kesimpulan, Kesimpulan diambil setelah data dan informasi yang sudah dianalisa secara komprehensif melalui berbagai sumber pustaka yang mendukung penelitian. 


\section{Sosio e-kons}

Volume 10, No. 2, Agustus 2018, pp. 96-108

e-ISSN: 2502-5449

p-ISSN: 2085-2266

http://journal.lppmunindra.ac.id/index.php/sosio_ekons

\section{HASIL DAN PEMBAHASAN}

\section{Profil KSU Syariah Huwaiza}

KSU Huwaiza dibentuk pada tahun 2002 melalui sekumpulan ibu-ibu rumah tangga yang berhimpun dalam komunitas pengajian. Pembentukan koperasi yang berlandaskan syariah dilatar belakangi upaya untuk saling tolong-menolong di antara anggota pengajian yang sedang

membutuhkan barang-barang keperluan rumah tangga, mensyiarkan ekonomi syariah yang tanpa riba (suku bunga), serta keprihatinan akan keberadaan bank keliing yang menawarkan pinjaman dengan pengembalian pokok plus bunga. Pada saat dibentuk, meski secara operasional berlandaskan syariah, namun masih berbadan hukum koperasi konvensional. KSU Huwaiza resmi menjadi koperasi berbadan hukum syariah pada tahun 2007.

Anggota KSU Huwaiza terbagi menjadi 2 macam yaitu anggota penuh dan anggota biasa. Anggota penuh adalah anggota pendiri yang memiliki simpanan wajib Rp 5 juta dan berhak ikut Rapat Anggota Tahunan (RAT) sedangkan anggota biasa memiliki simpanan wajib Rp 30.000,00 dan simpanan pokok Rp 50.000,00.

Tabel 2. Profil KSU Syariah Huwaiza

\begin{tabular}{ll}
\hline DATA KOPERASI & \\
\hline Koperasi & Koperasi Serba Usaha Syariah Huwaiza \\
\hline Nomor Badan Hukum & $75 /$ BH/KUKM/1.2/IV/2005 \\
\hline Tanggal Badan Hukum & $27 / 04 / 2005$ \\
\hline Tanggal RAT Terakhir & $15 / 04 / 2017$ \\
\hline Alamat & J1 Raya Parung Bingung \\
\hline Kelurahan / Desa & Rangkapan Jaya Baru \\
\hline Kecamatan & Pancoran Mas \\
\hline Kabupaten & Kota Depok \\
\hline Provinsi & Jawa Barat \\
\hline Bentuk Koperasi & Primer Kabupaten/Kota \\
\hline Jenis Koperasi & Konsumen \\
\hline Kelompok Koperasi & Kop. Serba Usaha \\
\hline Sektor Usaha & Jasa Keuangan dan Asuransi \\
\hline DATA PENGURUS & \\
\hline Nama Ketua & Namah Purnama, Amd \\
\hline Nama Sekretaris & Komariah, SPd \\
\hline Nama Bendahara & Erni Nurmayanti \\
\hline DATA KELEMBAGAAN & \\
\hline Jumlah Anggota Pria & 1,257 \\
\hline Jumlah Anggota Wanita & 1,489 \\
\hline Total Anggota & 2,746 \\
\hline Total Manajer & 0 \\
\hline Total Karyawan & 0 \\
\hline DATA LAINNYA & \\
\hline Nomor Induk Koperasi (NIK) & 3276020060023 \\
\hline Sertifikat & Sudah Bersertifikat \\
\hline Grade & A \\
\hline Sumber: Depkop.go.id & \\
\hline
\end{tabular}


Volume 10, No. 2, Agustus 2018, pp. 96-108

e-ISSN: 2502-5449

p-ISSN: 2085-2266

http://journal.lppmunindra.ac.id/index.php/sosio_ekons

\section{Kinerja Keuangan KSU Syariah Huwaiza}

Berikut ini ditampilkan data-data yang diperoleh dari hasil dokumentasi yang bersumber dari Laporan Kinerja 2015 Koperasi syariah Huwaiza yang meliputi data-data rasio keuangan, perkembangan aset dan SHU.

Tabel 3. Rasio Keuangan 2014 dan 2015

\begin{tabular}{|c|c|c|c|}
\hline Rasio & Komponen & $2014(\operatorname{Rp})$ & 2015 (Rp) \\
\hline ROA & $\frac{\text { Total Pendapatan }}{\text { Total Aset }}$ & $\frac{946.273 .014}{4.691 .375 .841}=20 \%$ & $\frac{942.839 .386}{4.630 .762 .211}=20 \%$ \\
\hline ROEA & $\begin{array}{l}\text { Total Pendapatan } \\
\text { Total Aktiva } \\
\text { Produktif }\end{array}$ & $\frac{946.273 .014}{3.890 .803 .565}=24 \%$ & $\frac{942.839 .386}{3.402 .921 .230}=27 \%$ \\
\hline ROE & $\begin{array}{l}\text { Total Pendapatan } \\
\text { Total Modal } \\
\end{array}$ & $\frac{946.273 .014}{305.253 .853}=310 \%$ & $\frac{942.839 .386}{329.567 .373}=286 \%$ \\
\hline FDR & $\begin{array}{l}\frac{\text { Total Pembiayaan }}{\text { Total Dana Pihak }} \\
\text { Ketiga }\end{array}$ & $\frac{2.913 .966 .273}{4.343 .954 .868}=67 \%$ & $\frac{2.479 .318 .270}{4.301 .194 .338}=58 \%$ \\
\hline BOPO & $\begin{array}{l}\frac{\text { Total Biaya }}{\text { Operasional }} \\
\text { Total Pendapatan }\end{array}$ & $\frac{899.899 .012}{946.273 .014}=95 \%$ & $\frac{910.546 .041}{942.839 .386}=97 \%$ \\
\hline
\end{tabular}

Sumber: RAT KSU Huwaiza (2016)

Tabel di atas memperlihatkan kinerja keuangan KSU Huwaiza selama tahun 2014 dan 2015 berdasarkan ROA, ROEA, ROE, FDR dan BOPO. ROA dan ROEA digunakan untuk mengukur tingkat penghasilan bersih yang diperoleh dari total aktiva perusahaan (Syamsudin, 2009:73). Tabel 3 menunjukkan bahwa hasil analisis ROA KSU Huwaiza untuk tahun 2014 dan 2015 adalah stabil. Sedangkan ROEA menunjukkan hasil yang meningkat. Apabila dibandingkan dengan standar kinerja menurut Bank Indonesia (Lestari, 2013), nilai ROA dan ROEA ini masuk kategori sangat baik karena berada diatas $1,215 \%$. Ini menunjukkan aset yang dimiliki KSU Huwaiza sudah optimal menghasilkan laba.

Rasio ROE dan ROEA digunakan untuk mengukur tingkat penghasilan bersih yang diperoleh oleh pemilik perusahaan atas modal yang diinvestasikan (Syamsudin, 2009:74). Nilai ROE tahun 2015 menunjukkan penurunan. Apabila dibandingkan dengan standar kinerja menurut BI (Lestari, 2013), kinerja KSU Huwaiza dalam menghasilkan laba yang berasal dari modal berada pada kategori sangat baik karena berada diatas 1,215\%.

Rasio FDR adalah perbandingan antara pembiayaan yang diberikan oleh bank dengan dana pihak ketiga yang berhasil dikerahkan oleh Bank. Nilai FDR pada tahun 2014 adalah sebesar 67\% sedangkan pada tahun 2015 sebesar 58\%. Berdasarkan Surat Edaran Bank Indonesia No. 26/5/BPPP tanggal 29 Mei 1993, besarnya Loan to Deposit Ratio (LDR atau FDR) yang ditetapkan oleh Bank Indonesia tidak boleh melebihi $110 \%$. Oleh sebab itu, nilai FDR KSU Huwaiza masih dalam kategori baik.

Rasio BOPO sendiri digunakan untuk mengukur tingkat efisiensi dan kemampuan bank dalam melakukan kegiatan operasinya (Dendawijaya, 2003:98) dalam (Ananda, 2013). Hasil rasio sebesar 95\% pada tahun 2014 dan 97\% pada tahun 2015 menunjukkan KSU Huwaiza berada pada peringkat buruk karena rasio BOPO berada di atas $89 \%$. 


\section{Sosio e-kons}

Volume 10, No. 2, Agustus 2018, pp. 96-108

e-ISSN: 2502-5449

p-ISSN: 2085-2266

http://journal.lppmunindra.ac.id/index.php/sosio_ekons

Tabel 4. Perkembangan Aset KSU Huwaiza

\begin{tabular}{cc}
\hline Tahun & Nilai (Milyar Rp) \\
\hline 2008 & $375.684 .157,97$ \\
\hline 2009 & $562.203 .141,20$ \\
\hline 2010 & $1.252 .686 .557,14$ \\
\hline 2011 & $2.591 .647 .727,00$ \\
\hline 2012 & $3.597 .549 .407,22$ \\
\hline 2013 & $4.458 .624 .453,38$ \\
\hline 2014 & $4.691 .375 .840,78$ \\
\hline 2015 & $4.630 .762 .210,94$ \\
\hline
\end{tabular}

Sumber: RAT KSU Huwaiza (2016)

Tabel 5. Perkembangan Sisa Hasil Usaha

\begin{tabular}{c|c}
\hline Tahun & Nilai (Juta Rp) \\
\hline 2005 & 2.018 \\
\hline 2006 & 4.770 \\
\hline 2007 & 4.523 \\
\hline 2008 & 7.718 \\
\hline 2009 & 9.300 \\
\hline 2010 & 22.779 \\
\hline 2011 & 37.011 \\
\hline 2012 & 46.893 \\
\hline 2013 & 43.041 \\
\hline 2014 & 46.374 \\
\hline 2015 & 32.293 \\
\hline
\end{tabular}

Sumber: RAT KSU Huwaiza (2016)

Berdasarkan Tabel 4 dan 5 di atas menunjukkan bahwa kinerja perkembangan aset mengalami peningkatan dari 2008 sampai dengan 2013 dan stabil pada 2014/2015. Sedangkan SHU KSU Huwaiza menunjukkan trend perkembangan yang meningkat namun fluktuatif, dan pada 2015 mengalami penurunan yang cukup berarti.

\section{Pendampingan Mitra Pembiayaan}

Berikut ditampilkan tabel berupa hasil wawancara terstruktur tentang kinerja koperasi syariah Huwaiza dalam memberikan pendampingan terhadap anggota yang dibiayainya.

Tabel 6. Bentuk Pendampingan Mitra Pembiayaan

\begin{tabular}{clcc}
\hline No & \multicolumn{1}{c}{ Bentuk Pendampingan } & Ya & Tidak \\
\hline 1 & $\begin{array}{l}\text { Membantu pelaku usaha mikro dalam memasarkan } \\
\text { barang/jasa milik pelaku usaha mikro }\end{array}$ & $\sqrt{ }$ \\
\hline 2 & $\begin{array}{l}\text { Membantu membangun jejaring pemasaran/penjualan } \\
\text { barang /jasa pelaku usaha mikro }\end{array}$ & $\sqrt{ }$ \\
\hline 3 & $\begin{array}{l}\text { Memberikan info-info baru tentang produk/jasa milik } \\
\text { Koperasi yang bermanfaat untuk pelaku usaha mikro }\end{array}$ & $\sqrt{ }$ \\
\hline 4 & $\begin{array}{l}\text { Memberikan penyuluhan tentang bagaimana menjaga } \\
\text { kepatuhan pada peraturan yang dibuat pemda/tertib } \\
\text { berbisnis sesuai aturan yang berlaku (aspek kepatuhan } \\
\text { pada hukum yang berlaku) }\end{array}$ & $\sqrt{ }$ \\
\hline 5 & Membantu pelaku usaha dalam penyediaan barang & $\sqrt{ }$ \\
\hline
\end{tabular}




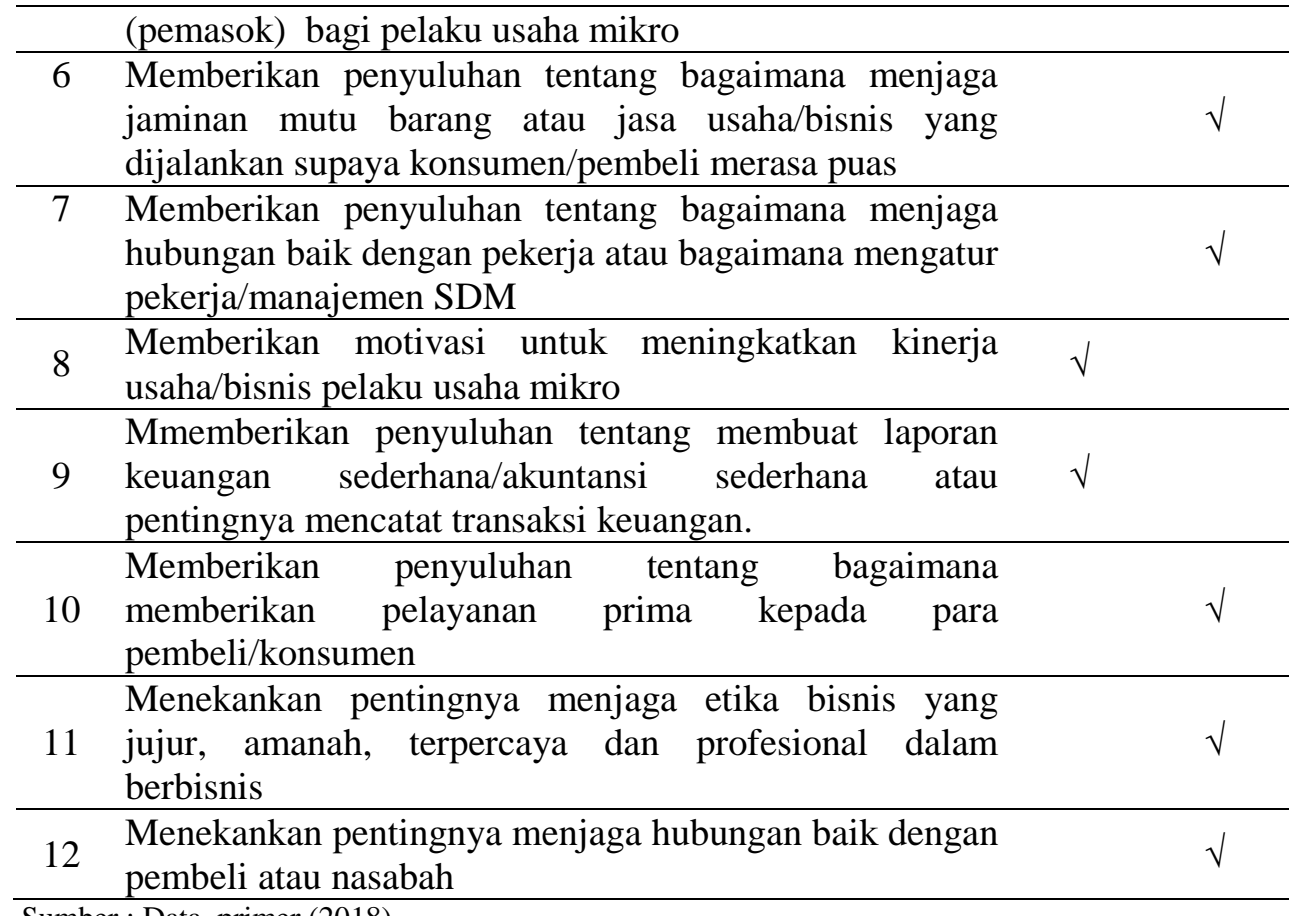

Sumber : Data primer (2018)

Berdasarkan Tabel 6 tersebut dapat diketehui bahwa sebagian besar pengelola koperasi syariah Huwaiza tidak banyak memberikan pendampingan kepada anggota yang dibiayainya. Pihak koperasi hanya memberikan informasi seputar produk baru kepada anggotanya, berupaya memotivasi anggota dalam menjalankan usahanya serta memberikan pengetahuan tentang pembuatan laporan keuangan secara sederhana.

Penelitian-penelitian yang terkait dengan peran perempuan dalam bidang ekonomi terbatas hanya menyoroti ruang lingkup yang lebih sempit dalam lingkungan keluarga seperti yang dilakukan oleh Mustika (2016) yang fokus pada hasil dari program PEKKA (Program Pemberdayaan Perempuan Kepala Keluarga) di kota Cimahi, Jawa Barat. Mustika (2016) menilai bahwa program PEKKA secara tidak lamgsung mampu memberdayakan perempuan di bidang ekonomi keluarga dalam upaya mnambah penghasilan keluarga melalui kegiatan pelatihan, magang, pemberian modal dan pendampingan. Demikian pula dengan penelitian yang dilakukan oleh Hasanah (2013) tentang program Simpan Pinjam Perempuan (SPP) di pedesaan Yogyakarta.

Sedangkan hasil penelitian ini leboih menyoroti peran perempuan secara makro dalam bidang pembangunan di wilayah Depok yang secara laangsung menunjukkan peran nyata dalam pembangunan ekonomi Depok, Jawa Barat. Meskipun kinerja koperasi di bidang pembinaan usaha anggotanya melalui pendekatan secara personal atas usaha yang dijalankan anggotanya belum berjalan maksimal -mengingat bahwa salah satu tujuan koperasi syariah berdiri adalah mengembangkan dan membina usaha anggotanya menjadi lebih maju- namun kinerja koperasi syariah Huwaiza sangat lebih maju jika dibandingkan dengan Program Simpan Pinjam Perempuan (SPP) yang merupakan lanjutan dari Program Pengembangan Kecamatan, bagian dari Program Pemerintah Nasional Pemberdayaan Masyarakat Mandiri Pedesaan (PNPM Mandiri Pedesaan) yang telah dilaksanakan di pedesaan Yogyakarta. Program Simpan Pinjam Perempuan (SPP) ditujukan untuk pemberdayaan perempuan dalam peningkatan ekonomi keluarga. Menurut Hasanah (2013). Program SPP menyasar kelompok perempuan dengan syarat-syarat 1) beranggotakan perempuan yang memiliki ikatan pemersatu dan telah mengenal minimal selama setahun, 2) Mempunyai kegiatan simpan pinjam dengan aturan pengelolaan dana simpan pinjam yang telah disepakati 3) Telah mempunyai modal dan simpanan dari 
anggota sebagai sumber dana pinjama yang diberikan, 4) Kelompok pinjaman masih berlangsung dengan baik dan 5) Mempunyai organisasi kelomok dan adminsitrasi sederhana. Syarat-syarat tersebut merupakan ketentuan bagi kelompok perempuan yang akan memperoleh pendanaan dari PNPM Mandiri Pedesaan.

Berdasarkan hasil penelitian Hasanah (2013) di daerah pedesaan Yogyakarta bahwa program SPP yang dijalankan oleh organisasi kelompok perempuan masih beroperasi secara konvensional yaitu simpan pinjam berbasis bunga. Dasar orientasi program SPP pun terbatas pada upaya peningkatan kesejahteraan ekonomi keluarga di pedesaan terutama keluarga miskin.

Jika dibandingkan dengan kelompok perempuan yang mendapatkan pendanaan program SPP tersebut, maka KSU Huwaiza yang berada di Depok, Jawa Barat menunjukkan kinerja yang jauh lebih maju dengan menjalankan simpan pinjam berbasis syariah. Maka dapat dikatakan bahwa KSU Huwaiza merupakan koperasi simpan pinjam yang digagas oleh perempuan dan secara nyata telah berkiprah untuk pembangunan ekonomi di wilayah Depok khususnya. Pemerintah kota Depok pun telah mengakui kinerja KSU Huwaiza melalui 2 kali penghargaan yang telah diberikan pada 2010 daan 2016. KSU Huwaiza melebih program SPP yang dijalankan oleh pemerintah Nasional melalui PNPM Mandiri Pedesaan.

Kehadiran koperasi yang berprinsip syariah tidak banyak di tengah masyarakat. Apalagi yang dipelopori oleh perempuan. Salah satu koperasi syariah adalah KSU Huwaiza yang pendiriannya diprakarsai oleh sekelompok perempuan yang berhimpun dalam komunitas pengajian. KSU Huwaiza bergerak dalam bidang simpan pinjam yang dijalankan dengan berpedoman pada aturan syariah Islam.

Koperasi Huwaiza pada dasarnya dibangun untuk membantu kebutuhan finansial para anggotanya. Peningkatan kinerja koperasi tidak lepas dari kerja keras para pengelola yang berjumlah 7 orang dan 3 orang pengurus yang berusaha membangun koperasi syariah Huwaiza menjadi berkembang dan meningkat baik dari segi aset maupun SHU untuk para anggotanya.

Salah satu prinsip syariah yang mendasari pembentukan koperasi syariah menurut Aziz (2005) adalah adanya kesetaraan gender dan non diskriminatif. Berdasarkan prinsip tersebut bahwa koperasi Huwaiza membagi peran secara proporsional dan adil dalam upayanya membangun kinerja koperasi. Para pengurus yang semuanya perempuan membagi tugas dan tanggungjawab masing-masing pekerjaan sesuai kapasitasnya secara non diskriminatif menurut gendernya. Para perempuan yang memprakarsai pembentukan koperasi menjadi pengurus koperasi, sedangkan Sumber Daya Insani (SDI) yang mengelola koperasi untuk posisi manajer, funding dan pembiayaan yang lebih banyak berhubungan dengan eksternal dan marketing ditangani oleh laki-laki sedangkan bagian internal dikelola oleh SDI perempuaan yang meliputi operasional, teller dan customer service.

Para perempuan yang menjadi pengurus koperasi beranggapan bahwa posisi tertentu seperti manajer, pengumpulan serta penyaluran dana kepada anggotanya ditangani oleh lakilaki yang dinilai lebih dinamis karena pengumpulan dana pada awal berdirinya dilakukan dengan cara jemput bola turun langsung ke lapangan dan senantiasa agresif berupaya mencari mitra untuk kerjasama. Kinerja koperasi juga tidak luput dari dewan pengawas yang terdiri dari sejumlah laki-laki yang mengawasi bagian syariah dan manajemen.

Pelaksanaan prinsip kesetaraan gender yang tepat dengan pembagian tugas yang bersifat non diskriminatif serta adil menurut proporsi tugas dan tanggung jawab sesuai gender, membuat koperasi syariah Huwaiza mampu meningkatkan aset dan menambah jumlah anggota koperasi. Semakin bertambahnya jumlah anggota mengindikasikan bahwa koperasi syariah Huwaiza mampu menunjukkan kepercayaan dan kinerja yang positif kepada para anggotanya. Keberhasilan tersebut menyebabkan koperasi Huwaiza sebanyak 2 kali mendapatkan penghargaan dari pemerintah kota Depok sebagai koperasi terbaik pada 2010 dan 2016.

Dengan demikian peran perempuan dalam membangun kinerja koperasi Huwaiza yang berprinsip syariah dilakukan secara tidak langsung dengan cara mendelegasikan posisi-posisi sesuai gendernya masing-masing. Peran perempuan dalam membangun kinerja koperasi syariah 


\section{Sosio e-kons}

Volume 10, No. 2, Agustus 2018, pp. 96-108

e-ISSN: 2502-5449

p-ISSN: 2085-2266

http://journal.lppmunindra.ac.id/index.php/sosio_ekons

Huwaiza sebatas pemrakarsa dan pendorong manajemen yang merupakan pengelola koperasi supaya menjadi besar dan berkembang. Selain itu peran perempuan dalam meningkatkan kinerja koperasi syariah Huwaiza supaya sesuai prinsip syariah dengan melibatkan saran-saran dan pertimbangan dari pengawas syariah dan manajemen.

Dari pembahasan tersebut dapat disimpulkan bahwa peran perempuan dalam membangun kinerja koperasi yang berprinsip syariah adalah sebagai berikut: 1. Membagi tugas dan tanggung jawab sesuai gender menurut prinsip kesetaraan gender dan non diskriminatif, 2. Mendorong fungsi dan peran manajemen sebagai pengelola agar senantiasa berusaha meningkatkan kinerja dengan melibatkan saran-saran dan masukan dari pengawas bidang manajemen. 3. Menjaga operasionalisasi koperasi supaya tetap berada di jalur syariah dengan melibatkan pengawas bagian syariah.

Prestasi sebanyak 2 kali yang pernah diraih oleh koperasi syariah Huwaiza menunjukkan bahwa dibalik keberhasilan tersebut terdapat peran perempuan yang berusaha terlibat dan berpartisipasi aktif dalam proses pembangunan perekonomian masyarakat, khususnya di bidang ekonomi syariah. Meskipun demikian masih banyak kekurangan yang perlu mendapatkan perhatian dari para pengurus, pengelola dan pengawas supaya koperasi syariah Huwaiza menjadi lebih baik di masa yang akan datang. Kekurangan tersebut adalah : 1). Banyaknya dana simpanan anggota yang tidak dikelola produktif dimana dari sekitar 3000 anggota hanya 400 anggota yang terlibat aktif pembiayaan. 2). Pihak koperasi khawatir dan kurang memahami prinsip kehati-hatian dalam penyaluran pembiayaan. 3). Banyaknya biaya-biaya operasional yang menekan keuntungan koperasi sehingga SHU anggota cenderung fluktuatif tidak stabil. 4). Koperasi tidak menjadikan anggota yang dibiayai sebagai mitra sehingga tidak terjadi proses pendampingan dalam kegiatan usahanya.

Dengan demikian kinerja dan prestasi koperasi dapat dipertahankan dengan cara: 1). Kreatif mengelola dana simpanan anggota supaya lebih menguntungkan. 2). Menjaga prinsip kehati-hatian dalam penyaluran dana dengan memahami analisa pembiayaan secara akurat dan tepat. 3). Menjaga efisiensi biaya supaya keuntungan menjadi besar sehingga SHU anggota dapat ditingkatkan. 4). Koperasi membuat program yang terjadwal berupa pendampingan anggotanya agar terpelihara hubungan baik dengan anggota yang dibiayai oleh koperasi.

\section{SIMPULAN}

Peran perempuan dalam membangun kinerja koperasi berprinsip syariah dilakukan secara tidak langsung di garis depan akan tetapi melalui dukungan dari belakang terhadap pengelola selaku manajemen supaya selalu menjaga dan mendorong mereka selalu berkinerja baik dan menjaga kepatuhan terhadap syariah melalui saran-saran dan pertimbangan yang disampaikan oleh pengawas bagian syariah dan manajemen. Peran secara tidak langsung tersebut menyebabkan peningkatan aset dan bertambahnya jumlah anggota koperasi yang berpengaruh pada penerimaan penghargaan sebagai koperasi terbaik oleh pemerintah daerah setempat.

Peran perempuan sebagai pengurus koperasi yang berprinsip syariah perlu lebih ditingkatkan lagi dalam mengatasi kekurangan-kekurangan yang terdapat dalam koperasi dengan berusaha kreatif mengelola dana simpanan anggota, menjaga prinsip kehati-hatian penyaluran pmbiayaan, menjaga efisiensi dan membuat program pemdampingan terhadap anggota yang dibiayai oleh koperasi.

\section{DAFTAR RUJUKAN}

Ananda, M. Aditya. (2013). Analisis Pengaruh CAR, FDR, NPF dan BOPO terhadap ROA Bank Umum Syariah (Studi Kasus pada Bank Umum Syariah di Indonesia Periode 20102012). Tesis yang dipublikasikan. Diakses pada 22 Mei 2018. 


\section{Sosio e-kons}

Volume 10, No. 2, Agustus 2018, pp. 96-108

e-ISSN: 2502-5449

p-ISSN: 2085-2266

http://journal.lppmunindra.ac.id/index.php/sosio_ekons

Arikunto, Suharsimi. (2013). Prosedur Penelitian, Suatu Pendekatan Praktik. Penerbit Rineka Cipta. Jakarta

Aziz, M. Amin. (2005). Pedoman Perizinan BMT. Seri Pinbuk 001/04. Pinbuk Press. Jakarta. . (2005). AD/ART BMT. Seri Pinbuk 002/05. Pinbuk Press. Jakarta.

Bappenas.(2017). Pedoman Teknis Penyusunan Rencana Aksi Tujuan Pembangunan Berkelanjutan. Kementerian Perencanaan Pembangunan Nasional. Jakarta.

Hasanah, Siti. (2013). Pemberdayaan Perempuan Melalui Kegiatan Ekonomi Berkeadilan (Simpan Pinjam Syariah Perempuan). Jurnal Sawwa. Volume 9. Nomor 1. Oktober. Universitas Islam Negeri Walisongo. Semarang.

Kementerian Pemberdayaan Perempuan dan Perlindungan Anak. (2016). Pembangunan Manusia Berbasis Gender. Kementerian Pemberdayaan Perempuan dan Perlindungan Anak bekerjasama dengan Badan Pusat Statistik. Jakarta.

Koperasi Huwaiza. (2016). Laporan Kinerja Tahun Buku 2015. Disampaikan pada Rapat Anggota Tahunan XIII. Depok. 28 Februari 2016.

Lestari, Endah Tri. (2013). Analisis Rasio keuangan untuk Menilai Kinerja Keuangan Pada BMT Syariah Surya Dana Makmur di Tulung Klaten. Skripsi yang dipublikasikan. Diakses pada 15 Mei 2018.

Mustika, Wulan. (2016). Peran Perempuan dalam Program Pemberdayaan Masyarakat dan Pengaruhnya terhadap Sumbangan Ekonomi Keluarga. Skripsi. Fakultas Ekologi Manusia. Institut Pertanian Bogor.

Sugiyono. (2010). Metode Penelitian Bisnis. Penerbit Alfabeta. Bandung. 